\title{
Meditation, Stress Processes, and Telomere Biology
}

\author{
Quinn A. Conklin ${ }^{1}$, Alexandra D. Crosswell ${ }^{2}$, Clifford D. Saron ${ }^{1}$, and Elissa S. Epel ${ }^{2}$
}

1) University of California, Davis

2) University of California, San Francisco

Corresponding authors:

Quinn A. Conklin (qconklin@ucdavis.edu) \& Elissa S. Epel (Elissa.Epel@ucsf.edu)

\section{Acknowledgements}

The preparation of this review was supported by the NIMH 5T32MH020006-20 "Consortium in Affective Science" predoctoral training grant (QC), an NIA R24AG048024 grant (EE, AC), an NIH K01AG057859 grant (AC) and funds from Hershey Family Foundation (CS). We gratefully acknowledge Brandon G. King for his thoughtful feedback on earlier drafts of the manuscript. 


\begin{abstract}
Both theoretical and empirical work support the notion that meditation training can improve telomere regulation, which may ultimately contribute to healthy aging. Yet, the psychological and biological mechanisms underlying these changes remain underspecified, as do the contexts and boundary conditions in which these changes occur. Here we summarize studies investigating the effects of various meditation-based interventions on telomere biology, making suggestions for future research. We then propose a model describing how meditation training may impact acute and habitual stress responses as pathways to improved cell aging.
\end{abstract}


Telomeres are DNA-protein complexes that cap and protect eukaryotic chromosomes. These dynamic structures are regulated by an intricate system of proteins and other molecular components, including telomerase—an enzyme capable of elongating telomeres. When telomeres become too short, critical cellular events occur, including cell death or states of prolonged senescence and inflammatory output. As such, telomere length (TL) serves as a reliable indicator of many age-related diseases (e.g., dementia and heart disease [1]). Studies of genetics show that telomere biology plays a small but causal role in disease processes: for example, genetic loading for short TL predicts degenerative diseases such as cardiovascular disease, whereas genetic variation for longer telomeres predicts propensity for certain cancers, including glioma [2].

Telomeres generally shorten slowly across the lifespan. There is, however, some degree of malleability to this as telomeres tend to shorten more quickly in individuals exposed to longterm psychosocial adversity [3], but appear to stabilize or possibly lengthen in individuals engaged in positive lifestyle interventions (e.g., [4]). Meditation training is one such intervention that seems to beneficially affect telomere biology. In a previous theoretical model, we explored the impact of mindfulness meditation on TL [5]. In the decade since this model was published, a small body of research has emerged addressing the relationship between meditation practice and telomere-related outcomes (telomere length, telomerase activity, or telomere-related gene expression). Here, we review this empirical work and offer an updated model, depicted in Figure 1, which illustrates how various aspects of meditation training may impact telomeric regulation by influencing acute and habitual stress processes.

\section{What we know so far:}

A total of 19 studies have examined telomere biology in relation to meditation [6-24]. 
These studies vary in quality, though many constitute promising pilot studies that warrant replication and extension. Two cross-sectional studies found longer telomeres in experienced meditators compared to meditation-naive controls ( $n=20$ [7*]; $n=13$ [6], in women only). The remaining 17 studies examined telomere-related outcomes in relation to interventions involving or emphasizing meditation practice (Table 1). Of the eleven studies measuring telomerase activity (TA), nine found intervention-related increases [9,10,18-24] or higher TA in the treatment group following intervention [17], while two found no significant changes in TA $\left[8^{*}, 24\right]$. By contrast, just two of the nine studies measuring TL—which involved interventions of relatively high intensity or duration—showed increased TL in the treatment group [8*,23]. The remaining seven studies found no significant change in TL [9-15].

Only four studies have assessed TA and TL concurrently, each of which reported significant intervention-related changes in one measure but not the other $[8 *-10,24]$. These findings suggest that TA and TL have different kinetics and fluctuate on different time scales, consistent with the observation that TA and TL are generally uncorrelated in cross-sectional studies [25]. We hypothesize that meditation training promotes phasic increases in TA, which eventually lead to longer telomeres, though the duration of training needed to elicit these effects is unknown. Initial evidence suggests that these changes can happen rapidly: intensive retreat studies of experienced meditators have shown modest increases in TA in as little as one week [22*] and increases in TL in as little as three weeks [8*]. Because TA and TL were only assessed at the end of these interventions, the longevity of these effects is unknown.

It is largely assumed that meditation training influences telomere biology by reducing psychological stress, though only a few studies have assessed whether stress-related processes actually mediate these relationships. Intervention-related increases in TA have been linked to 
47 improvements in quality of life [19], fewer intrusive thoughts [23], and reductions in anxiety,

48 chronic stress, and basal cortisol [18]—-though these associations have not been observed in all cases $[9,14]$. Another study found that increases in perceived control and purpose in life, and decreases in neuroticism, were associated with higher levels of TA following an intensive retreat [17]. More direct tests of stress-related psychological and biological meditators are needed to better understand these relationships over time.

Although the available evidence suggests that meditation training can improve telomere maintenance, it is unclear how and under what conditions these effects are achieved, and how long they persist. Because telomere regulation is dynamic and involves complex temporal features that are not yet fully understood, future studies should include more frequent measurements using gold standard methods [26**,27**]. As telomere biology varies by cell type, it will be informative for studies to assess TL in tissues with stable cell type distributions (e.g., buccal cells), in addition to more commonly used blood samples, which include a mix of shifting immune cell types (see Lin et al. [27**] for a discussion of the pros and cons of measuring TL in different sample types and with various assay methods). Finally, to gain the clearest mechanistic understanding, studies should measure psychological and physiological stress processes alongside multiple indicators of telomere biology and other biomarkers of aging.

\section{Stress processes and their relation to telomere biology}

The acute stress response traditionally refers to a range of cognitive, affective, behavioral, and physiological reactions to discrete stressors [28*], which are shaped by cognitive biases and basal physiological states. This multi-system response can involve anticipatory arousal before a stressful event, peak reactivity during the event, and recovery to baseline following the event. Maladaptive forms of this acute stress response may lead to alterations in 
telomere regulation. For example, exaggerated autonomic reactivity has been associated with lower immune cell TA [29], and higher cortisol reactivity to stressors has been associated with shorter immune cell telomeres [30*] (but not buccal cell TL [31]). Perseverative cognitions, such as worry and rumination, can exacerbate profiles of heightened physiological reactivity and delayed recovery [32] and may serve as internal stressors in and of themselves. Importantly, shorter telomeres have also been linked to perseverative cognitions, including negative mind wandering [33] and greater anticipatory threat appraisals to an acute stressor [34].

Acute stress reactivity profiles are influenced by allostatic states, including basal levels of autonomic and neuroendocrine activity, metabolic hormones, and inflammation. Chronic exposure and prolonged reactivity to stressors can contribute to dysregulated allostatic states, with deleterious health consequences (e.g. [35]). Telomere regulation appears to be implicated in this relationship, as shorter telomeres and lower telomerase levels have been associated with lower vagal tone, and higher basal levels of cortisol, inflammation, and oxidative stress [3]. The acute stress response is activated by perceptions of threat to the physical or social self [36], yet these perceptions vary between people and between physical, social, and cultural contexts. Cognitive biases are the habitual mental filters that influence one's interpretations of the world, including mental representations of the self and others, and perceptions of one's environment. These cognitive biases are shaped by life experience. For example, having a history of early life adversity can lead one to anticipate negative events and to interpret neutral stimuli as negative (e.g. [37]). Cognitive biases that prime individuals to be hypervigilant to their environment—due to real or perceived threats—can lead to heightened allostatic states. It may be that regularly feeling unsafe indirectly signals to cellular mediators that it is more important to sustain heightened biological stress arousal (i.e., to be on alert for threats) than to put energy 
towards cellular restoration. Along these lines, personality traits such as pessimism, neuroticism, and hostility have been linked to prolonged stress reactivity and shorter telomeres [38], suggesting that one's habitual interpretations of the world contribute to the relationship between stress exposure and telomere regulation.

Initial evidence suggests that various forms of meditation training can beneficially affect

allostatic states (e.g., immune system functioning [39]) and the anticipatory [40], reactivity (e.g., [41]), and recovery [42] phases of the acute stress response. Yet these findings are inconsistent (for a review of cortisol studies, see [43]). Meditation interventions can vary significantly in the practices they emphasize, their pedagogical frameworks, and in their training environments—all of which may influence stress processes. Similarly, some practices may be more appropriate for particular individuals depending on the types of maladaptive stress responses they are most prone to (e.g., greater anticipatory threat or prolonged recovery). Accounting for these variables will facilitate more direct and nuanced hypothesis testing regarding the effects of meditation training on stress processes and outcomes.

\section{Effects of meditation training on stress processes}

Meditation practices represent a class of mental training techniques intended to regulate a range of psychological processes—particularly those having to do with perceptions of reality and the self $\left[44^{* *}, 45\right]$. As such, we expect these techniques to target the cognitive biases that shape acute stress appraisals and responses, as well as the perseverative cognitions that prolong stress reactivity. In this way, continued meditation training should support experiential learning and self-understanding that lead to lasting improvements in health.

Meditation techniques can be usefully categorized according to the cognitive mechanisms they are believed to target. One contemporary classification system posits three families of 
practice: attentional, deconstructive, and constructive [44**]. The attentional family comprises practices used to train the self-regulation of attention. One common practice involves continually directing attention to the unfolding of one's present-moment interoceptive or sensory experience (e.g., sensations of the breath), monitoring this attention, and bringing it back when it inevitably strays. Attention practices are thought to strengthen meta-awareness, the ability to observe and monitor one's internal processes of thinking and feeling [44**,45]. As a result, awareness is brought to bear on aspects of emotional experience that may otherwise go unnoticed, including bodily sensations, thoughts, and environmental stimuli, which may lead to improvements in emotion identification and regulation [46]. Training attention to one's presentmoment experience has also been shown to reduce elaborative processing of stimuli [47] and to inhibit habitual behavioral responding (e.g., [48]). These changes may lead to more efficient and flexible uses of attentional resources, promoting more accurate and less catastrophic appraisals of one's present experience, as well as more adaptive behavioral responses to stressful events. The deconstructive family refers to a set of self-inquiry techniques used to foster insight into processes of perception, emotion, and cognition. A common goal of such practices is to deconstruct maladaptive models of the self, others, and the world by interrogating the causes and conditions of one's present experience, and by observing the impermanence of phenomena (see [44**] for an illustration of this using the experience of anger as an example). One cognitive faculty targeted by deconstructive practices is dereification (also known as decentering or cognitive defusion), which occurs when thoughts, feelings, and perceptions are observed as temporary mental phenomena rather than accurate reflections of reality [44**-46]. Together, dereification and meta-awareness may disrupt perseverative cognitions as well as the negative self-concepts and excessive self-referential processing implicated in depression and anxiety 
139

140

141

142

143

144

145

146

147

148

149

150

151

152

153

154

155

156

157

158

159

160

161

$\left[44^{* *}, 45,49,50\right]$; they may also facilitate insights and reappraisals that support greater self-

acceptance. Thoughts and events may also appear less threatening when understood as impermanent phenomena, and the ability to observe unpleasant experiences with greater granularity may similarly lessen their potency. These changes are likely to minimize experiential avoidance [46], which, in turn, may break the cycle of anticipatory anxiety, heightened reactivity, and prolonged recovery, in favor of more adaptive stress response profiles. Finally, practices in the constructive family are intended to further cultivate psychological well-being by replacing maladaptive self-schemas with adaptive self-concepts [44**], and by developing prosocial qualities, such as kindness, compassion, empathetic joy and equanimity [51]. Psychological processes targeted by these practices include perspective taking, shifts in appraisal, and the generation of positive affect [44**,52], each of which may influence how acute stressors are perceived and responded to. These practices may be especially useful for managing acute stressors involving negative interactions with others. Indeed, initial evidence suggests that such practices alter acute responses to social-evaluative stressors. For instance, selfcompassion training attenuated physiological and subjective stress reactivity to the Trier Social Stress Test (TSST) [53], and interventions involving dyadic meditation practices reduced cortisol reactivity to the TSST compared to attention-focused training [54].

Though each of these families of practice are likely to influence telomere regulation, the boundaries between them are not clear cut. Some practices are likely to target multiple psychological processes, and most meditation interventions combine several different practice types, making it difficult to distinguish their individual contributions. Additionally, individuals will vary in how they interpret and implement these instructions [45], and the skills learned during formal meditation practice may manifest in a myriad of ways in daily life. 


\section{Meditation training contexts: safety and support}

Meditation training may uniquely affect stress responding by promoting perceptions of safety—safety within the context of the self, in social exchanges, and by providing physically safe environments. Traditional stress-health models assume that stress degrades health through repeated activation of acute stress response systems (e.g, [55]). By contrast, the generalized unsafety theory of stress assumes that stress-response systems are predisposed to respond to threats, and are only inhibited by learned safety cues, including the presence of trusted individuals [56*]. This reconfigured model shifts the emphasis from acute stressors that activate stress responses, to the safety signals needed to dampen a threat-detection system that is ever at the ready [56*]. From this perspective, fundamentally altering explicit and implicit appraisal processes that modulate stress responding may require learning, or re-learning, safety cues until they become believed and habitual.

Meditation training often occurs in the context of a highly supportive environment. Residential retreats are the most extreme and unique example of this, where individuals are sequestered from real-world threats and demands, in a safe natural environment with their basic needs taken care of (see King et al., this issue [57]). This may be a particularly beneficial training format for individuals prone to maladaptive acute stress responses or with more ingrained telomere vulnerability factors, including experiences of early adversity, insecure attachments [58], and neuroticism (the later indicated by our recent retreat study [8*]). Additionally, relationships with trusted teachers and a community of similarly motivated practitioners may promote feelings of safety and activate schemas of secure attachment and interconnectedness. These elements may play an important role in altering stress processes over and above the mental training aspects of meditation. 


\section{Conclusion}

186 We have outlined several potential mechanisms through which meditation training may improve 187 telomere biology via changes to habitual and acute stress processes (Figure 1). In articulating 188 these pathways, this model may help to explain why a variety of meditation interventions, as 189 well as other mind-body interventions, have been found to have positive effects on telomere 190 biology as well as other stress-sensitive biological outcomes. As methods of measuring telomere 191 biology become more reliable and available, the next generation of studies will be able to 192 determine more definitively if meditation interventions impact telomere biology in a meaningful 193 way. Understanding how these practices affect telomere biology will require a more systematic 194 investigation of the various dimensions that make up meditation interventions, as well as better 195 methods for capturing the phenomenological and psychological changes that might occur.

196 Despite the complexity of these mind-body relationships, there is still a tremendous amount that 197 can be learned about how meditation influences biological and cellular functioning. 


\section{References}

1. D’Mello MJJ, Ross SA, Briel M, Anand SS, Gerstein H, Paré G: Association Between Shortened Leukocyte Telomere Length and Cardiometabolic Outcomes. Circ Cardiovasc Genet 2015, 8:82-90.

2. Collaboration TTMR: Association between telomere length and risk of cancer and non-neoplastic diseases: A mendelian randomization study. JAMA Oncol 2017, 3:636651.

3. Epel ES, Prather AA: Stress, Telomeres, and Psychopathology: Toward a Deeper Understanding of a Triad of Early Aging. Annu Rev Clin Psychol 2018, 14:371-397.

4. Puterman E, Weiss J, Lin J, Schilf S, Slusher A, Johansen KL, Epel ES: Aerobic exercise lengthens telomeres and reduces stress in family caregivers: A randomized controlled trial - Curt Richter Award Paper 2018. Psychoneuroendocrinology 2018, In press.

5. Epel E, Daubenmier J, Moskowitz JT, Folkman S, Blackburn E: Can Meditation Slow Rate of Cellular Aging? Cognitive Stress, Mindfulness, and Telomeres. Ann N Y Acad Sci 2009, 1172:34-53.

6. Hoge EA, Chen MM, Orr E, Metcalf CA, Fischer LE, Pollack MH, DeVivo I, Simon NM: Loving-Kindness Meditation practice associated with longer telomeres in women. Brain Behav Immun 2013, 32:159-163.

7. *Alda M, Puebla-Guedea M, Rodero B, Demarzo M, Montero-Marin J, Roca M, GarciaCampayo J: Zen meditation, length of telomeres, and the role of experiential avoidance and compassion. Mindfulness (NY) 2016, 7:651-659. This is the only study to have assessed telomere length in relation to meditation practice using high-throughput quantitative fluorescence in situ hybridization (HT-Q-FISH). There are several methods for measuring telomere length. PCR is often the most feasible to implement, but only provides average telomere length estimates for a given sample. HT-Q-FISH is more costly but measures telomere length in individual cells, providing more granular information.

8. *Conklin QA, King BG, Zanesco AP, Lin J, Hamidi AB, Pokorny JJ, Álvarez-López MJ, Cosín-Tomás M, Huang C, Kaliman P, et al.: Insight meditation and telomere biology: The effects of intensive retreat and the moderating role of personality. Brain Behav Immun 2018, 70:233-245. This was the first study of a meditation intervention to measure telomere length, telomerase activity and telomere related genes in a pre-post design. The authors report increased telomere length and changes in telomere-maintenance genes suggesting improved maintenance within a three-week period.

9. Lengacher CA, Reich RR, Kip KE, Barta M, Ramesar S, Paterson CL, Moscoso MS, Carranza I, Budhrani PH, Kim SJ, et al.: Influence of Mindfulness-Based Stress Reduction (MBSR) on Telomerase Activity in Women With Breast Cancer (BC). Biol Res Nurs 2014, 16:438-447. 
10. Tolahunase M, Sagar R, Dada R: Impact of Yoga and Meditation on Cellular Aging in Apparently Healthy Individuals: A Prospective, Open-Label Single-Arm Exploratory Study. Oxid Med Cell Longev 2017.

11. Rima D, Shiv BK, Bhavna C, Shilpa B, Saima K: Oxidative Stress Induced Damage to Paternal Genome and Impact of Meditation and Yoga - Can it Reduce Incidence of Childhood Cancer? Asian Pacific J cancer Prev APJCP 2016, 17:4517-4525.

12. Wang X, Sundquist K, Hedelius A, Palmér K, Memon AA, Sundquist J: Leukocyte telomere length and depression, anxiety and stress and adjustment disorders in primary health care patients. BMC Psychiatry 2017, 17:148.

13. Thimmapuram J, Pargament R, Sibliss K, Grim R, Risques R, Toorens E: Effect of heartfulness meditation on burnout, emotional wellness, and telomere length in health care professionals. J Community Hosp Intern Med Perspect 2017, 7:21-27.

14. Carlson LE, Beattie TL, Giese-Davis J, Faris P, Tamagawa R, Fick LJ, Degelman ES, Speca M: Mindfulness-based cancer recovery and supportive-expressive therapy maintain telomere length relative to controls in distressed breast cancer survivors. Cancer 2015, 121:476-484.

15. Duraimani S, Schneider RH, Randall OS, Nidich SI, Xu S, Ketete M, Rainforth MA, Gaylord-King C, Salerno JW, Fagan J: Effects of Lifestyle Modification on Telomerase Gene Expression in Hypertensive Patients: A Pilot Trial of Stress Reduction and Health Education Programs in African Americans. PLoS One 2015, 10:e0142689.

16. Bhasin MK, Dusek JA, Chang B-H, Joseph MG, Denninger JW, Fricchione GL, Benson H, Libermann TA: Relaxation Response Induces Temporal Transcriptome Changes in Energy Metabolism, Insulin Secretion and Inflammatory Pathways. PLoS One 2013, 8:e62817.

17. Jacobs TL, Epel ES, Lin J, Blackburn EH, Wolkowitz OM, Bridwell DA, Zanesco AP, Aichele SR, Sahdra BK, MacLean KA, et al.: Intensive meditation training, immune cell telomerase activity, and psychological mediators. Psychoneuroendocrinology 2011, 36:664-681.

18. Daubenmier J, Lin J, Blackburn E, Hecht FM, Kristeller J, Maninger N, Kuwata M, Bacchetti P, Havel PJ, Epel E: Changes in stress, eating, and metabolic factors are related to changes in telomerase activity in a randomized mindfulness intervention pilot study. Psychoneuroendocrinology 2012, 37:917-928.

19. Lavretsky H, Epel ES, Siddarth P, Nazarian N, Cyr N St., Khalsa DS, Lin J, Blackburn E, Irwin MR: A pilot study of yogic meditation for family dementia caregivers with depressive symptoms: effects on mental health, cognition, and telomerase activity. Int J Geriatr Psychiatry 2012, 28:57-65.

20. Rao KS, Chakraharti SK, Dongare VS, Chetana K, Ramirez CM, Koka PS, Deb KD: Antiaging Effects of an Intensive Mind and Body Therapeutic Program through 
Enhancement of Telomerase Activity and Adult Stem Cell Counts. J Stem Cells 2015, 10:107-125.

21. Kumar SB, Yadav R, Yadav RK, Tolahunase M, Dada R: Telomerase Activity and Cellular Aging Might Be Positively Modified by a Yoga-Based Lifestyle Intervention. J Altern Complement Med 2015, 21:370-372.

22. *Epel ES, Puterman E, Lin J, Blackburn EH, Lum PY, Beckmann ND, Zhu J, Lee E, Gilbert A, Rissman RA, et al.: Meditation and vacation effects have an impact on disease-associated molecular phenotypes. Transl Psychiatry 2016, 6:e880. This is the only meditation retreat study to account for the effects of the retreat environment and removal from daily life stressors by comparing experienced meditation practitioners, novice practitioners, and a vacation control group living in the same retreat environment.

23. Ornish D, Lin J, Daubenmier J, Weidner G, Epel E, Kemp C, Magbanua MJM, Marlin R, Yglecias L, Carroll PR, et al.: Increased telomerase activity and comprehensive lifestyle changes: a pilot study. Lancet Oncol 2008, 9:1048-1057.

24. Ornish D, Lin J, Chan JM, Epel E, Kemp C, Weidner G, Marlin R, Frenda SJ, Magbanua MJM, Daubenmier J, et al.: Effect of comprehensive lifestyle changes on telomerase activity and telomere length in men with biopsy-proven low-risk prostate cancer: 5year follow-up of a descriptive pilot study. Lancet Oncol 2013, 14:1112-1120.

25. Lin J, Epel E, Cheon J, Kroenke C, Sinclair E, Bigos M, Wolkowitz O, Mellon S, Blackburn E: Analyses and comparisons of telomerase activity and telomere length in human T and B cells: Insights for epidemiology of telomere maintenance. J Immunol Methods 2010, 352:71-80.

26. $* *$ Thomas S: Telomeres as Sentinels for Environmental Exposures, Psychosocial Stress, and Disease Susceptibility. National Institute of Environmental Health Sciences and the National Institute on Aging Workshop Summary 2017. At this workshop, leading experts in telomere biology discussed the challenges and opportunities of telomere research. This meeting summary offers an excellent overview for researchers new to the area

27. **Lin J, Smith DL, Esteves K, Drury S: Telomere length measurement by qPCR Summary of critical factors and recommendations for assay design.

Psychoneuroendocrinology 2018, In press. This review summarizes issues that arise when telomere length is measured using qPCR —addressing the selection of biological samples (e.g. blood, saliva etc.), the collection and storage of samples, and the DNA extraction and post-extraction phases of the assay procedure. The authors provide recommendations and guidance based on current literature.

28. *Epel ES, Crosswell AD, Mayer SE, Prather AA, Slavich GM, Puterman E, Mendes WB: More than a feeling: A unified view of stress measurement for population science. Front Neuroendocrinol 2018, 49:146-169. This paper presents a multi-level and integrative working model that articulates how stress exposures across the life course can influence stress reactivity and habitual responding to daily events, ultimately leading to 
disease development.

29. Epel ES, Lin J, Wilhelm FH, Wolkowitz OM, Cawthon R, Adler NE, Dolbier C, Mendes WB, Blackburn EH: Cell aging in relation to stress arousal and cardiovascular disease risk factors. Psychoneuroendocrinology 2006, 31:277-287.

30. *Steptoe A, Hamer M, Lin J, Blackburn EH, Erusalimsky JD: The longitudinal relationship between cortisol responses to mental stress and leukocyte telomere attrition. J Clin Endocrinol Metab 2016, 102:jc.2016-3035. This longitudinal study examined the association between telomere length and cortisol reactivity to an acute challenge, finding that greater cortisol reactivity predicted telomere attrition 3 years later.

31. Woody A, Hamilton K, Livitz IE, Figueroa WS, Zoccola PM: Buccal telomere length and its associations with cortisol, heart rate variability, heart rate, and blood pressure responses to an acute social evaluative stressor in college students. Stress 2017, 20:249-257.

32. Zoccola PM, Dickerson SS: Assessing the relationship between rumination and cortisol: a review. J Psychosom Res 2012, 73:1-9.

33. Epel ES, Puterman E, Lin J, Blackburn E, Lazaro A, Mendes WB: Wandering Minds and Aging Cells. Clin Psychol Sci 2013, 1:75-83.

34. O’Donovan A, Tomiyama AJ, Lin J, Puterman E, Adler NE, Kemeny M, Wolkowitz OM, Blackburn EH, Epel ES: Stress appraisals and cellular aging: A key role for anticipatory threat in the relationship between psychological stress and telomere length. Brain Behav Immun 2012, 26:573-579.

35. McEwen BS: Mood disorders and allostatic load. Biol Psychiatry 2003, 54:200-207.

36. Dickerson SS, Kemeny ME: Acute Stressors and Cortisol Responses: A Theoretical Integration and Synthesis of Laboratory Research. Psychol Bull 2004, 130:355-391.

37. Chen E, Langer D a, Raphaelson YE, Matthews K a: Socioeconomic status and health in adolescents: the role of stress interpretations. Child Dev 2015, 75:1039-1052.

38. Lin J, Epel E, Blackburn E: Telomeres and lifestyle factors: Roles in cellular aging. Mutat Res Mol Mech Mutagen 2012, 730:85-89.

39. Black DS, Slavich GM: Mindfulness meditation and the immune system: a systematic review of randomized controlled trials. Ann N Y Acad Sci 2016, 1373:13-24.

40. Turan B, Foltz C, Cavanagh JF, Alan Wallace B, Cullen M, Rosenberg EL, Jennings PA, Ekman P, Kemeny ME: Anticipatory sensitization to repeated stressors: The role of initial cortisol reactivity and meditation/emotion skills training.

Psychoneuroendocrinology 2015, 52:229-238.

41. Rosenkranz MA, Lutz A, Perlman DM, Bachhuber DRW, Schuyler BS, MacCoon DG, 
Davidson RJ: Reduced stress and inflammatory responsiveness in experienced meditators compared to a matched healthy control group. Psychoneuroendocrinology 2016, 68:117-25.

42. Crosswell AD, Moreno PI, Raposa EB, Motivala SJ, Stanton AL, Ganz PA, Bower JE: Effects of mindfulness training on emotional and physiologic recovery from induced negative affect. Psychoneuroendocrinology 2017, 86:78-86.

43. O’Leary K, O’Neill S, Dockray S: A systematic review of the effects of mindfulness interventions on cortisol. J Health Psychol 2016, 21:2108-2121.

44. **Dahl CJ, Lutz A, Davidson RJ: Reconstructing and deconstructing the self: cognitive mechanisms in meditation practice. Trends Cogn Sci 2015, 19:515-523. These authors present a novel typology of meditation, classifying practices into three broad families based on the cognitive processes they are thought to target. This framework is useful for developing theories and making mechanistic predictions about specific practices.

45. Lutz A, Jha AP, Dunne JD, Saron CD: Investigating the phenomenological matrix of mindfulness-related practices from a neurocognitive perspective. Am Psychol 2015, 70:632-658.

46. Chambers R, Gullone E, Allen NB: Mindful emotion regulation: An integrative review. Clin Psychol Rev 2009, 29:560-572.

47. Slagter HA, Lutz A, Greischar LL, Francis AD, Nieuwenhuis S, Davis JM, Davidson RJ: Mental Training Affects Distribution of Limited Brain Resources. PLoS Biol 2007, 5:e138.

48. Zanesco AP, King BG, MacLean KA, Saron CD: Cognitive Aging and Long-Term Maintenance of Attentional Improvements Following Meditation Training. $J$ Cogn Enhanc 2018, 2:259-275.

49. Lebois LAM, Papies EK, Gopinath K, Cabanban R, Quigley KS, Krishnamurthy V, Barrett LF, Barsalou LW: A shift in perspective: Decentering through mindful attention to imagined stressful events. Neuropsychologia 2015, 75:505-524.

50. Teasdale JD, Segal Z, Williams JMG: How does cognitive therapy prevent depressive relapse and why should attentional control (mindfulness) training help? Behav Res Ther 1995, 33:25-39.

51. Wallace BA, Houshmand Z: The four immeasurables: practices to open the heart. Snow Lion Publications, 2010.

52. Engen HG, Singer T: Affect and Motivation Are Critical in Constructive Meditation. Trends Cogn Sci 2016, 20:159-160.

53. Arch JJ, Brown KW, Dean DJ, Landy LN, Brown KD, Laudenslager ML: Self- 
compassion training modulates alpha-amylase, heart rate variability, and subjective responses to social evaluative threat in women. Psychoneuroendocrinology 2014, 42:49-58.

54. Engert V, Kok BE, Papassotiriou I, Chrousos GP, Singer T: Specific reduction in cortisol stress reactivity after social but not attention-based mental training. Sci Adv 2017, 3:e1700495.

55. Mcewen B: McEwen BS. Stress, adaptation, and disease. Allostasis and allostatic load. Ann NY Acad Sci 1998, 840: 33-44.

56. *Brosschot J, Verkuil B, Thayer J, Brosschot JF, Verkuil B, Thayer JF: Generalized Unsafety Theory of Stress: Unsafe Environments and Conditions, and the Default Stress Response. Int J Environ Res Public Health 2018, 15:464. This paper outlines a novel theory of psychological stress, which posits that individuals' have an innate threatdetection system that is suppressed by learned safety cues. This model accounts for the occurrence of prolonged physiological stress responses that occur in the absence of any direct or acute stress stimuli (e.g., loneliness in humans), suggesting that these responses result from a lack of perceived safety.

57. King, BG, Conklin, QA, Zanesco, AP, Saron, CD: Residential meditation retreats: their role in contemplative practice and significance for psychological research. Curr Opin Psychol Under review.

58. Ein-Dor T, Mikulincer M, Shaver PR: Attachment insecurities and the processing of threat-related information: Studying the schemas involved in insecure people's coping strategies. J Pers Soc Psychol 2011, 101:78-93.

59. Bormann JE, Carrico AW: Increases in Positive Reappraisal Coping During a GroupBased Mantram Intervention Mediate Sustained Reductions in Anger in HIVPositive Persons. Int J Behav Med 2009, 16:74-80.

60. Campbell TS, Labelle LE, Bacon SL, Faris P, Carlson LE: Impact of Mindfulness-Based Stress Reduction (MBSR) on attention, rumination and resting blood pressure in women with cancer: A waitlist-controlled study. J Behav Med 2012, 35:262-271.

61. Zanesco AP, King BG, MacLean KA, Jacobs TL, Aichele SR, Wallace BA, Smallwood J, Schooler JW, Saron CD: Meditation training influences mind wandering and mindless reading. Psychol Conscious Theory, Res Pract 2016, 3:12-33.

62. Epel E: How “reversible” is telomeric aging? Cancer Prev Res 2012, 5:1163-1168. 


\section{Running head: Meditation, Stress Processes, and Telomere Biology}

Table 1: Meditation Interventions Measuring Telomere Outcomes

\begin{tabular}{|c|c|c|c|c|c|c|c|c|c|c|}
\hline Study & Participants & $\begin{array}{c}\text { Random } \\
\text { assignment }\end{array}$ & Control treatment & Target intervention & Target intervention length and intensity & Sample collection & Cell type & $\begin{array}{c}\text { Telomere-related } \\
\text { measures }\end{array}$ & Assay method & Results \\
\hline Jacobs et al. (2011) & $\begin{array}{l}\text { Healthy experienced } \\
\text { meditators }\end{array}$ & Yes & $\begin{array}{l}\text { Wait-list } \\
(n=25)\end{array}$ & $\begin{array}{l}\text { Shamatha meditation } \\
\text { retreat }(n=17)\end{array}$ & $\begin{array}{l}12 \text { weeks: silent residential retreat } \\
\text { including meditation } ~ 6 \mathrm{~h} / \mathrm{d}+\text { vegetarian diet }\end{array}$ & Week 12 & PBMCs & Telomerase activity & $\begin{array}{l}\text { TRAPeze kit } \\
\text { (Chemicon) }\end{array}$ & $\begin{array}{l}\text { Greater TA in retreatants than controls post-retreat; } \\
\text { TA was mediated by } \uparrow \text { perceived control } \\
\text { and } \downarrow \text { neuroticisism in retreatants }\end{array}$ \\
\hline Daubenmier et al. (2012) & $\begin{array}{l}\text { Overweight/obese } \\
\text { women }\end{array}$ & Yes & $\begin{array}{l}\text { Wait-list } \\
(n=18)\end{array}$ & $\begin{array}{l}\text { Mindfulness-based } \\
\text { intervention for } \\
\text { stress eating }(n=19)\end{array}$ & $\begin{array}{l}16 \text { weeks: nine } 2.5 \mathrm{~h} \text { group sessions } \\
\quad+1 \text {-day silent retreat }\end{array}$ & Baseline, post & PBMCs & Telomerase activity & $\begin{array}{l}\text { TRAPeze kit } \\
\text { (Chemicon) }\end{array}$ & $\begin{array}{l}\uparrow \text { TA in both groups; changes in TA were negatively } \\
\text { correlated with chronic stress, anxiety, dietary restraint, } \\
\text { dietary fat intake, cortisol, and glucose }\end{array}$ \\
\hline Lavretsky et al. (2013) & Dementia caregivers & Yes & $\begin{array}{l}\text { Listening to relaxation } \\
\quad \text { music }(n=16)\end{array}$ & Kirtan kriya $(n=23)$ & 8 weeks: cd-led meditation $12 \mathrm{~m} / \mathrm{d}$ & Baseline, post & PBMCs & Telomerase activity & $\begin{array}{l}\text { TRAPeze kit } \\
\text { (Chemicon) }\end{array}$ & $\begin{array}{l}\uparrow \text { TA in meditators but not relaxation controls; } \\
\uparrow \text { TA was associated with } \uparrow \text { quality of life } \\
\text { in the meditators only }\end{array}$ \\
\hline Rao et al. (2015) & Healthy novices & - & None & $\begin{array}{l}\text { Mindbody therapy } \\
\text { retreat }(n=108)\end{array}$ & $\begin{array}{l}3 \text { weeks: residential retreat including } \\
1 \mathrm{~h} / \mathrm{d} \text { yoga } \& \text { breath exercises } \\
+2 \mathrm{~h} / \mathrm{d} \text { meditation + vegetarian diet }\end{array}$ & Baseline, week 3 & PBMCs & Telomerase activity & $\begin{array}{l}\text { TRAPeze kit } \\
\text { (Millipore) }\end{array}$ & $\begin{array}{l}\uparrow \text { TA: } 45 \% \text { of people showed } \\
\text { TA increases of one-fold or more }\end{array}$ \\
\hline Kumar et al. (2015) & 31-year-old obese man & - & None & $\begin{array}{l}\text { Yoga-based lifestyle } \\
\text { intervention }(n=1)\end{array}$ & $\begin{array}{l}10 \text { days: active intervention with instructor } 2 \mathrm{~h} / d \text {, } \\
\text { followed by 90-day self-directed practice }\end{array}$ & $\begin{array}{l}\text { Baseline, day } 10, \\
\quad \text { day } 90\end{array}$ & PBMCs & Telomerase activity & $\begin{array}{l}\text { Telomerase assay kit } \\
\text { (Roche, Switzerland); } \\
\text { QPCR }\end{array}$ & $\uparrow \mathrm{TA}$ \\
\hline Epel et al. (2016) & $\begin{array}{l}\text { Healthy experienced } \\
\text { meditators } \\
\quad \& \text { novices }\end{array}$ & $\begin{array}{l}\text { Novice \& } \\
\text { vacation } \\
\text { controls, yes; } \\
\text { experienced } \\
\text { meditators, no }\end{array}$ & $\begin{array}{l}\text { Vacation controls }(\mathrm{n}=31) \\
\& \text { novice medititors on } \\
\text { retreat }(\mathrm{n}=33)\end{array}$ & $\begin{array}{l}\text { Primordial sound } \\
\text { meditation retreat } \\
\qquad(n=30)\end{array}$ & $\begin{array}{l}4 \text { days: residential retreat including } \\
\text { meditation } 3 / \mathrm{h}+\mathrm{d} \text { yogag } 2 \mathrm{~h} / \mathrm{d}+\text { lectures } \\
\text { + interactive self-reflection exercises }\end{array}$ & $\begin{array}{l}\text { Baseline, day } 6 \text {, } \\
\text { week } 4 \text {, month } 10\end{array}$ & PBMCs & $\begin{array}{l}\text { Telomerase activity \& } \\
\text { telomere-related genes }\end{array}$ & $\begin{array}{l}\text { TRAPeze kit } \\
\text { (Millipore) }\end{array}$ & $\begin{array}{l}\uparrow \mathrm{TA} \text { in experienced meditators (lower at baseline) } \\
\text { but not novices or vacation controls }\end{array}$ \\
\hline Ornish et al. (2008) & $\begin{array}{l}\text { Low-risk prostate } \\
\text { cancer patients }\end{array}$ & - & None & $\begin{array}{l}\text { Comprehensive lifestyle } \\
\text { intervention }(n=30)\end{array}$ & $\begin{array}{l}12 \text { weeks: yoga \& meditation } 6 \mathrm{~h} / \mathrm{w} \\
\text { + moderate exercise } 3 \mathrm{~h} / \mathrm{w}+\text { group support 1h/w } \\
\text { + meetings with health staff } 4 \mathrm{~h} / \mathrm{w} \\
\quad+\text { regimented diet }+3 \text {-day retreat }\end{array}$ & Baseline, week 12 & PBMCs & Telomerase activity & $\begin{array}{l}\text { TRAPeze kit } \\
\text { (Chemicon) }\end{array}$ & $\begin{array}{l}\uparrow \text { TA associated with } \downarrow \text { in LDL cholesterol } \\
\text { and } \downarrow \text { intrusive thoughts }\end{array}$ \\
\hline Ornish et al. (2013) & $\begin{array}{l}\text { Low-risk prostate } \\
\text { cancer patients }\end{array}$ & No & $\begin{array}{l}\text { Active observation } \\
\qquad(n=25)\end{array}$ & $\begin{array}{l}\text { Comprehensive lifestyle } \\
\text { intervention }(n=10)\end{array}$ & $\begin{array}{l}\text { Optional attendance of two } 4 \mathrm{~h} \text { meetings/month } \\
\text { following the intervention described above }\end{array}$ & Baseline, year 4-5 & PBMCs & $\begin{array}{l}\text { Telomerase activity \& } \\
\text { telomere length }\end{array}$ & $\begin{array}{l}\text { TRAPeze kit (Millipore); } \\
\text { qRT-PCR }\end{array}$ & $\begin{array}{l}\text { ns } \downarrow \text { TA in both groups } \\
\uparrow \mathrm{TL} \text { in treatment group compared to } \downarrow \text { TL in controls }\end{array}$ \\
\hline Conklin et al. (2018) & $\begin{array}{l}\text { Healthy experienced } \\
\text { meditators }\end{array}$ & No & $\begin{array}{l}\text { Life as usual } \\
\qquad(n=34)\end{array}$ & $\begin{array}{l}\text { Insight meditation retreat } \\
\qquad(n=28)\end{array}$ & $\begin{array}{l}4 \text { weeks: } ~ 9 \mathrm{~h} / \mathrm{d} \text { meditation during silent } \\
\text { residential retreat + vegetarian diet }\end{array}$ & Baseline, week 3 & PBMCs & $\begin{array}{l}\text { Telomerase activity, } \\
\text { telomere length, \& } \\
\text { telomere-related genes }\end{array}$ & $\begin{array}{l}\text { TRAPeze kit (Millipore); } \\
\text { qRT-PCR }\end{array}$ & $\begin{array}{l}\text { No change in } \mathrm{TA} \text {; } \uparrow \mathrm{TL} \text { in retreatants, which was } \\
\text { moderated by levels of agreeableness and neuroticism; } \\
\text { changes in gene expression supporting improved } \\
\text { telomere maintenance }\end{array}$ \\
\hline Lengacher et al. (2014) & Breast cancer patients & Yes & $\begin{array}{l}\text { Treatment as usual } \\
\qquad(n=64)\end{array}$ & $\begin{array}{l}\text { Variation of MBSR } \\
\qquad(n=70)\end{array}$ & $\begin{array}{l}6 \text { weeks: meditation \& hatha yoga } \\
\text { group sessions } 2 \mathrm{~h} / \mathrm{w}+15-45 \mathrm{~m} / \mathrm{d} \text { formal } \\
\text { meditation }+15-45 \mathrm{~m} / \mathrm{d} \text { informal practice }\end{array}$ & $\begin{array}{l}\text { Baseline, week } 6 \text {, } \\
\text { week } 12\end{array}$ & PBMCs & $\begin{array}{l}\text { Telomerase activity \& } \\
\text { telomere length }\end{array}$ & $\begin{array}{l}\text { TRAPeze kit (Chemicon); } \\
\text { qRT-PCR }\end{array}$ & $\begin{array}{l}\uparrow \text { TA in MBSR participants (lower at baseline) } \\
\text { compared to controls; } \\
\text { No change in TL }\end{array}$ \\
\hline Tolahunase et al. (2017) & Healthy participants & - & None & $\begin{array}{l}\text { Yoga and meditation } \\
\text { lifestyle intervention } \\
\qquad(n=96)\end{array}$ & $\begin{array}{l}12 \text { weeks: } 120 \mathrm{~m} \text { sessions including yoga, } \\
\text { meditation, \& instruction } 5 \mathrm{~d} / \mathrm{w}\end{array}$ & Baseline, week 12 & PBMCs & $\begin{array}{l}\text { Telomerase activity \& } \\
\text { telomere length }\end{array}$ & $\begin{array}{l}\text { Telomerase assay kit } \\
\text { (Roche, Switzerland); } \\
\text { qPCR }\end{array}$ & $\uparrow \mathrm{TA} ; \mathrm{ns} \uparrow \mathrm{TL}$ \\
\hline Rima et al. (2016) & $\begin{array}{l}\text { Fathers of } \\
\text { retinoblastoma } \\
\text { affected children }\end{array}$ & - & $\begin{array}{l}\text { Age-matched men w/ a } \\
\text { healthy child born in } \\
\text { the last year }(n=50)\end{array}$ & $\begin{array}{l}\text { Yoga and meditation } \\
\text { lifestyle intervention } \\
\qquad(n=56)\end{array}$ & 6 months: theory \& practice sessions 2h/d & $\begin{array}{l}\text { Baseline, week 12, } \\
\text { month } 6\end{array}$ & Sperm & Telomere length & ELISA & $\begin{array}{l}\text { TL ns shorter in fathers of children } \\
\text { with RB than controls; } \\
\text { No reported change in TL }\end{array}$ \\
\hline Wang et al. (2017) & $\begin{array}{l}\text { Patients with } \\
\text { depression, anxiety or } \\
\text { stress \& adjustment } \\
\text { disorders }\end{array}$ & Yes & $\begin{array}{l}\text { Treatment as usual } \\
\text { (mostly CBT; } n=320)\end{array}$ & $\begin{array}{l}\text { Mindfulness-based group } \\
\text { therapy }(n=181)\end{array}$ & $\begin{array}{l}8 \text { weeks: mindfulness-based group therapy } 2 \mathrm{~h} / \mathrm{w} \\
+ \text { meditation } 20 \mathrm{~m} / \mathrm{d}\end{array}$ & Baseline, week 8 & PBMCs & Telomere length & qRT-PCR & No change in TL \\
\hline Thimmapuram et al. (2017) & $\begin{array}{l}\text { Residents, faculty } \\
\text { physicians \& nurses }\end{array}$ & No & Life as usual $(n=12)$ & $\begin{array}{l}\text { Heartfulness meditation } \\
\qquad(n=35)\end{array}$ & $\begin{array}{l}12 \text { weeks: meditation } 20 \mathrm{~m} / \text { morning } \\
+5 \mathrm{~m} \text { before bed + group session led by } \\
\text { heartfulness trainer } 30 \mathrm{~m} / \mathrm{w}\end{array}$ & Baseline, week 12 & Saliva & Telomere length & $\begin{array}{l}\text { Salivary kits (DNA, } \\
\text { Genotek Inc., CA); qPCR }\end{array}$ & $\begin{array}{l}\text { No change in TL overall; } \\
\uparrow \mathrm{TL} \text { in meditators under } 33 \text { years old }\end{array}$ \\
\hline Carlson et al. (2015) & $\begin{array}{l}\text { Breast cancer } \\
\text { survivors }\end{array}$ & Yes & $\begin{array}{l}\text { 12-week supportive- } \\
\text { expressive therapy } \\
\text { (SET; } n=36) \text {, or 1-day stress } \\
\text { management seminar }(n=18)\end{array}$ & $\begin{array}{l}\text { Mindfulness-based cancer } \\
\text { recovery (MBCR; n=34) }\end{array}$ & $\begin{array}{l}8 \text { weeks: group meetings } 1.5 \mathrm{~h} / \mathrm{w} \\
\quad+1 \text { day silent retreat }\end{array}$ & $\begin{array}{l}\text { MBSR: Baseline, week 8; } \\
\text { SET: Baseline, week 12; } \\
\text { Control: Baseline, week } 10\end{array}$ & $\begin{array}{l}\text { Whole } \\
\text { blood }\end{array}$ & Telomere length & qPCR & $\begin{array}{l}\text { TL was maintained in both intervention groups, } \\
\text { but declined in controls }\end{array}$ \\
\hline Duraimnai et al. (2015) & $\begin{array}{l}\text { Hypertensive } \\
\text { African Americans }\end{array}$ & $\begin{array}{l}\text { To parent study, } \\
\text { but not this sub- } \\
\text { study }\end{array}$ & $\begin{array}{l}\text { Extensive health } \\
\text { eduction program } \\
\qquad(n=24)\end{array}$ & $\begin{array}{l}\text { TM meditation + health } \\
\text { education course }(n=24)\end{array}$ & $\begin{array}{l}16 \text { weeks: } 1.5-\text {-hh meetings for first } 6 \text { days } \\
+ \text { th meetings follow-up twice/month } \\
\text { + two } 20 \mathrm{~m} \text { meditation sessions/d }\end{array}$ & Baseline, week 16 & Serum & $\begin{array}{l}\text { Telomere length \& } \\
\text { hTR anhTERT mRNA } \\
\quad \text { expression }\end{array}$ & qRT-PCR & $\begin{array}{c}\uparrow \mathrm{hTR} \text { and hTERT mRNA expression in both groups; } \\
\text { No change in TL }\end{array}$ \\
\hline Bhasin et al. (2013) & Healthy novices & No & $\begin{array}{l}\text { Experienced practitioners } \\
\text { maintaining their own } \\
\text { practice }(n=26)\end{array}$ & $\begin{array}{l}\text { Relaxation Response } \\
\text { (RR) training }(n=26)\end{array}$ & $\begin{array}{l}8 \text { weeks: weekly individual training sessions } \\
\quad \text { from an experienced clinician } \\
\quad+\text { cd-led home practice } 20 \mathrm{~m} / \text { day }\end{array}$ & $\begin{array}{l}\text { Baseline, post: } \\
\text { Samples were taken pior to, } \\
\text { immediately after, and } 15 \\
\text { minutes after listening to an } \\
\text { RR-eliciting or health } \\
\text { education recording }\end{array}$ & PBMCs & $\begin{array}{l}\text { Telomere-related gene } \\
\text { expression }\end{array}$ & $\begin{array}{l}\text { Transcriptional profiling } \\
\text { using Affymetrix human } \\
\text { genome high throughput } \\
\text { array plates analyzed by } \\
\text { dChip }\end{array}$ & $\begin{array}{l}\text { Higher expression of telomere maintenance genes (i.e., } \\
\text { HIST1H2BC, CACNA1C, and CYC1) in long-term } \\
\text { practitioners than novices (before or after 8-week } \\
\text { training) at baseline, which } \downarrow \text { in response to the RR } \\
\text { induction }\end{array}$ \\
\hline
\end{tabular}

Note: $\mathrm{m}=\mathrm{min}$; $\mathrm{h}=$ hour; $\mathrm{d}=$ day; $\mathrm{w}=$ =week; $\uparrow$ = increases; $\downarrow$ = decreases; ns = not significant 


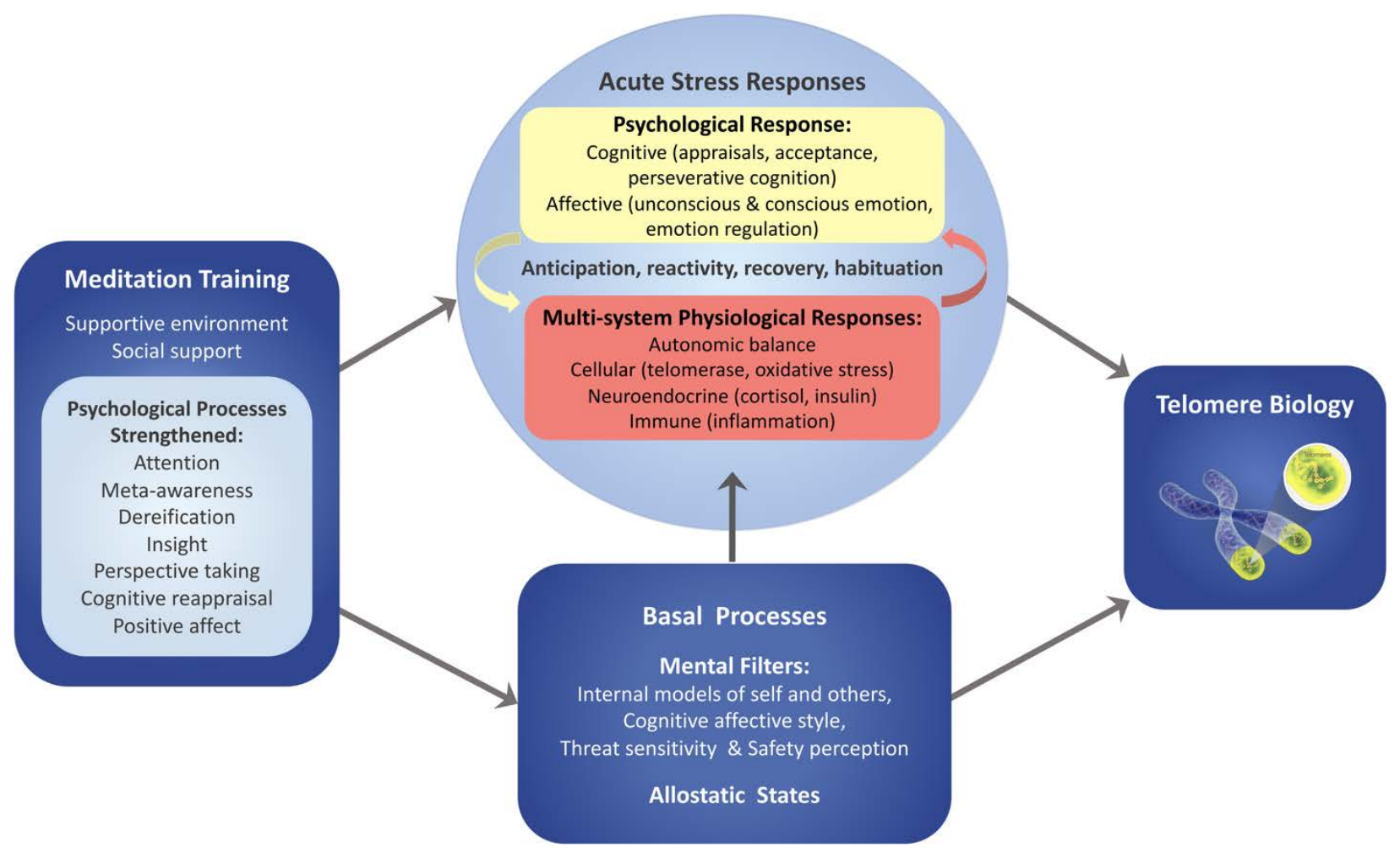

Figure 1: A theoretical model depicting how meditation training impacts telomere biology via stress processes (adapted from Figure 1 of Epel and Crosswell, et al. [28*]). Meditation training is expected to alter basal processes that influence acute stress responses, potentially resulting in fewer overall stress reactions. Training may also provide tools to reduce the severity of acute responses when they do occur. Only some of the mechanistic pathways proposed here have been tested. For example, there is evidence for the link between stress appraisals and telomere length [34] and for the ability of meditation training to enhance positive reappraisals (e.g., [59]), yet no intervention study has simultaneously assessed changes in stress appraisals and telomere biology to test this mediational pathway. With regard to perseverative cognitions, there is evidence that meditation training reduces rumination [60] and mind wandering [61], and that negative mind wandering is related to shorter telomeres [33], but no study has tested the association between telomere length and rumination. One small study of prostate cancer patients did, however, find that intervention-related increases in TA were associated with declines in individual's intrusive thoughts about their diagnosis [23]. While this study found that changes in avoidance were not related to increases in TA, another study found that telomere length was inversely related to experiential avoidance [ $\left.7^{*}\right]$. Intervention-related increases in TA have also been linked to declines in morning cortisol [18], though no meditation intervention study has assessed acute reactivity in relation to telomere outcomes. Finally, there are multiple biological mechanisms that may result in TL changes, including increases in intracellular TA, alternative lengthening of telomeres, latent virus reactivation, and shifts in cell distributions [62]. These biological mechanisms will need to be considered to map out a more complete model. 